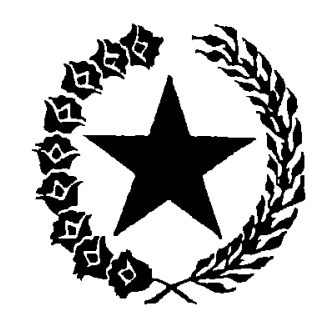

PRESIDEN

REPU日LIK INDONESIA

UNDANG-UNDANG REPUBLIK INDONESIA

NOMOR 14 TAHUN 2019

TENTANG

PEKERJA SOSIAL

DENGAN RAHMAT TUHAN YANG MAHA ESA

PRESIDEN REPUBLIK INDONESIA,

\begin{abstract}
Menimbang : a. bahwa negara bertanggung jawab untuk melindungi segenap bangsa, memajukan kesejahteraan umum, dan mewujudkan keadilan sosial bagi seluruh rakyat Indonesia yang dilakukan melalui penyelenggaraan kesejahteraan sosial;

b. bahwa penyelenggaraan kesejahteraan sosial saat ini belum optimal dan terjadi perubahan sosial di dalam masyarakat yang berdampak pada peningkatan jumlah dan kompleksitas permasalahan kesejahteraan sosial;

c. bahwa permasalahan kesejahteraan sosial perlu ditangani melalui praktik pekerjaan sosial yang profesional, terencana, terpadu, berkualitas, dan berkesinambungan untuk memperbaiki dan meningkatkan keberfungsian sosial;

d. bahwa pengaturan pekerja sosial masih bersifat parsial dan belum sepenuhnya diatur dalam suatu ketentuan peraturan perundang-undangan;

e. bahwa berdasarkan pertimbangan sebagaimana dimaksud dalam huruf $a$, huruf $b$, huruf $c$, dan huruf d, perlu membentuk Undang-Undang tentang Pekerja Sosial;
\end{abstract}

Mengingat : Pasal 20 dan Pasal 21 Undang-Undang Dasar Negara Republik Indonesia Tahun 1945; 


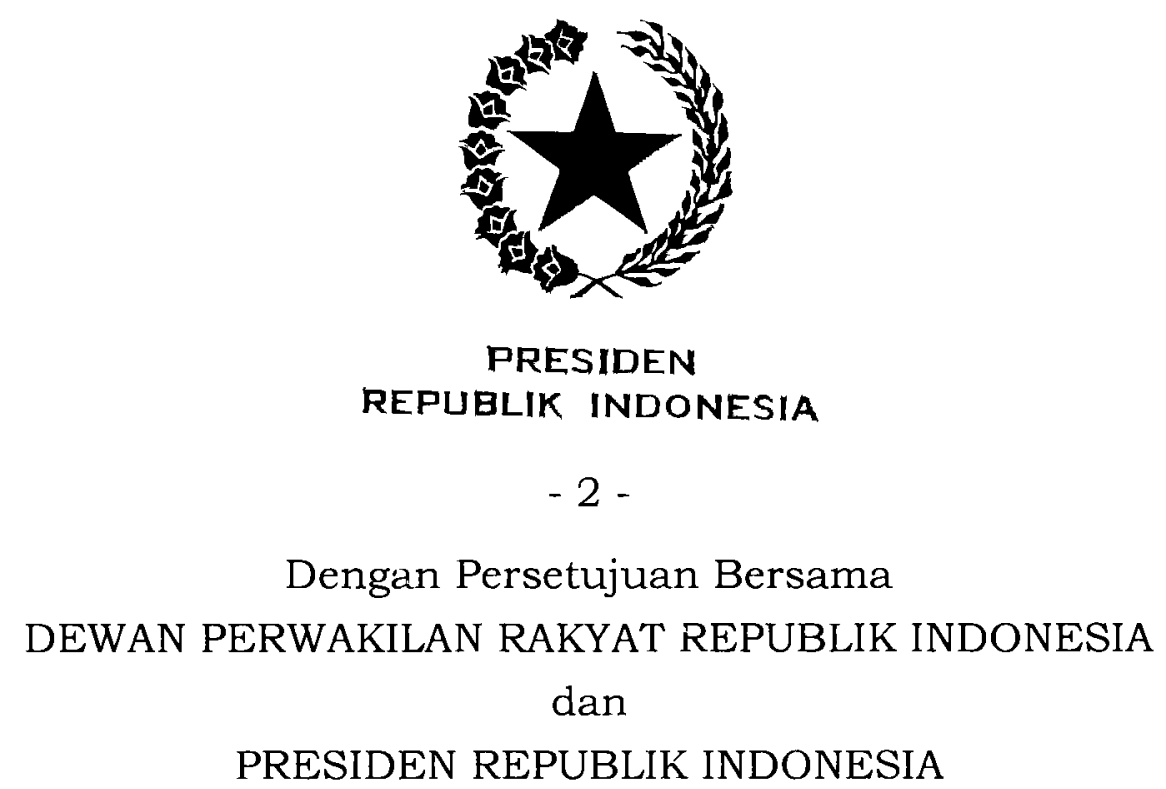

MEMUTUSKAN:

Menetapkan : UNDANG-UNDANG TENTANG PEKERJA SOSIAL

BAB I

KETENTUAN UMUM

Pasal 1

Dalam Undang-Undang ini yang dimaksud dengan:

1. Pekerja Sosial adalah seseorang yang memiliki pengetahuan, keterampilan, dan nilai praktik pekerjaan sosial serta telah mendapatkan sertifikat kompetensi.

2. Praktik Pekerjaan Sosial adalah penyelenggaraan pertolongan profesional yang terencana, terpadu, berkesinambungan dan tersupervisi untuk mencegah disfungsi sosial, serta memulihkan dan meningkatkan keberfungsian sosial individu, keluarga, kelompok, dan masyarakat.

3. Keberfungsian Sosial adalah suatu kond1si yang memungkinkan individu, keluarga, kelompok, dan masyarakat mampu memenuhi kebutuhan dan hak dasarnya, melaksanakan tugas dan peranan sosialnya, serta mengatasi masalah dalam kehidupannya.

4. Pencegahan Disfungsi Sosial adalah upaya untuk mencegah keterbatasan individu, keluarga, kelompok, dan masyarakat dalam menjalankan keberfungsian sosiainya. 


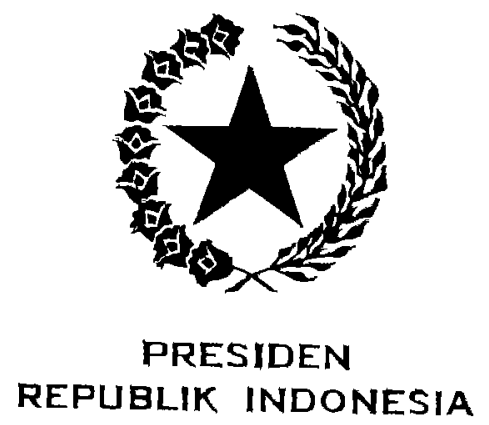

$-3-$

5. Rehabilitasi Sosial adalah proses refungsionalisasi dan pengembangan untuk memungkinkan seseorang mampu melaksanakan fungsi sosialnya secara wajar dalam kehidupan masyarakat.

6. Pemberdayaan Sosial adalah upaya yang diarahkan untuk menjadikan individu, keluarga, kelompok, dan masyarakat yang mengalami masalah sosial agar berdaya sehingga mampu memenuhi kebutuhan dasarnya.

7. Pengembangan Sosial adalah upaya untuk meningkatkan dan mengembangkan kemampuan atau daya guna individu, keluarga, kelompok, dan masyarakat yang sudah berfungsi dengan baik.

8. Pelindungan Sosial adalah upaya yang diarahkan untuk mencegah dan menangani risiko dari guncangan dan kerentanan sosial.

9. Klien adalah penerima manfaat pelayanan Praktik Pekerjaan Sosial yang meliputi individu, keluarga, kelompok, dan masyarakat.

10. Sertifikat Kompetensi adalah surat tanda pengakuan secara hukum terhadap kompetensi Pekerja Sosial untuk dapat menjalankan praktik di seluruh Indonesia setelah lulus Uji Kompetensi.

11. Uji Kompetensi adalah proses penilaian kompetensi secara terukur dan objektif untuk menilai capaian kompetensi dalam Praktik Pekerjaan Sosial dengan mengacu pada standar kompetensi.

12. Registrasi adalah pencatatan resmi terhadap Pekerja Sosial yang memiliki Sertifikat Kompetensi untuk menjalankan Praktik Pekerjaan Sosial di Organisasi Pekerja Sosial. 


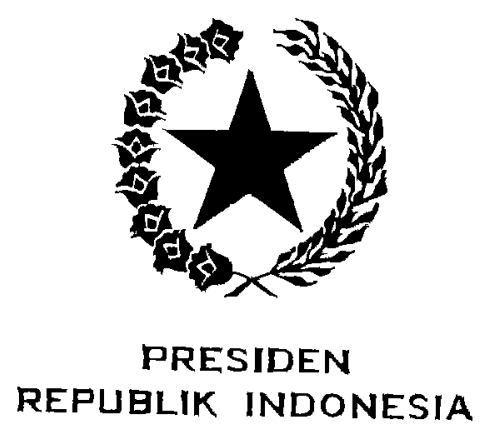

$-4-$

13. Surat Tanda Registrasi yang selanjutnya disingkat STR adalah bukti tertulis yang diberikan oleh Organisasi Pekerja Sosial kepada Pekerja Sosial yang telah diregistrasi.

14. Registrasi Ulang adalah pencatatan ulang terhadap Pekerja Sosial yang telah diregistrasi setelah memenuhi persyaratan yang berlaku.

15. Surat Izin Praktik Pekerja Sosial yang selanjutnya disingkat SIPPS adalah bukti tertulis yang diberikan oleh pemerintah daerah kabupaten/kota kepada Pekerja Sosial sebagai pemberian kewenangan untuk menjalankan Praktik Pekerjaan Sosial.

16. Organisasi Pekerja Sosial adalah wadah berhimpun Pekerja Sosial yang bersifat independen, mandiri, dan berbadan hukum.

17. Pemerintah Pusat adalah Presiden Republik Indonesia yang memegang kekuasaan pemerintahan negara Republik Indonesia yang dibantu oleh Wakil Presiden dan menteri sebagaimana dimaksud dalam UndangUndang Dasar Negara Republik Indonesia Tahun 1945.

18. Pemerintah Daerah adalah kepala daerah sebagai unsur penyelenggara pemerintahan daerah yang memimpin pelaksanaan urusan pemerintahan yang menjadi kewenangan daerah otonom.

19. Menteri adalah menteri yang menyelenggarakan urusan pemerintahan di bidang sosial.

\section{Pasal 2}

Pekerja Sosial melaksanakan Praktik Pekerjaan Sosial dengan berasaskan:

a. nondiskriminatif;

b. kesetiakawanan;

c. keadilan;

d. profesionalitas . . 


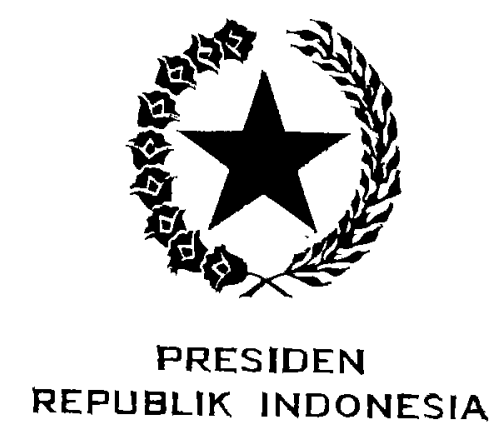

$-5-$

d. profesionalitas;

e. kemanfaatan;

f. keterpaduan;

g. kemitraan;

h. aksesibilitas; dan

1. akuntabilitas.

\section{Pasal 3}

Pekerja Sosial melaksanakan Praktik Pekerjaan Sosial dengan tujuan:

a. mencegah terjadinya disfungsi sosial individu, keluarga, kelompok, dan masyarakat;

b. memulihkan dan meningkatkan Keberfungsian Sosial individu, keluarga, kelompok, dan masyarakat;

c. meningkatkan ketahanan sosial masyarakat dalam menghadapi masalah kesejahteraan sosial;

d. meningkatkan kualitas manajemen penyelenggaraan kesejahteraan sosial dalam rangka mencapai kemandirian individu, keluarga, kelompok, dan masyarakat; dan

e. meningkatkan kemampuan dan kepedulian masyarakat dalam penyelenggaraan kesejahteraan sosial secara melembaga dan berkelanjutan.

BAB II

PRAKTIK PEKERJAAN SOSIAL

\section{Bagian Kesatu}

Umum

\section{Pasal 4}

Praktik Pekerjaan Sosial meliputi:

a. Pencegahan Disfungsi Sosial;

b. Pelindungan Sosial; 


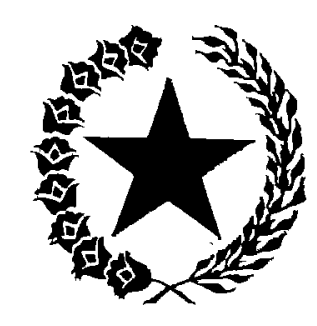

PRESIDEN

REPUBLIK INDONESIA

$-6-$

c. Rehabilitasi Sosial;

d. Pemberdayaan Sosial; dan

e. Pengembangan Sosial.

\title{
Pasal 5
}

Praktik Pekerjaan Sosial harus dilengkapi dengan sarana dan prasarana pelayanan sesuai dengan standar pelayanan dan standar operasional prosedur.

\author{
Bagian Kedua \\ Péncegahan Disfungsi Sosial
}

\section{Pasal 6}

(1) Pencegahan Disfungsi Sosial sebagaimana dimaksud dalam Pasal 4 huruf a merupakan intervensi pekerjaan sosial yang ditujukan untuk mencegah terjadinya disfungsi sosial individu, keluarga, kelompok, dan masyarakat.

(2) Pencegahan Disfungsi Sosial sebagaimana dimaksud pada ayat (1) dilakukan dalam bentuk:

a. penyuluhan sosial;

b. bimbingan sosial;

c. pendampingan sosial;

d. peningkatan kapasitas;

e. pelatihan keterampilan;

f. pelayanan aksesibilitas;

g. advokasi sosial; daríatau

h. Pencegahan Disfungsi Sosial bentuk lain.

(3) Pencegahan Disfungsi Sosial bentuk lain sebagaimana dimaksud pada ayat (2) huruf h ditetapkan oleh Menteri. 


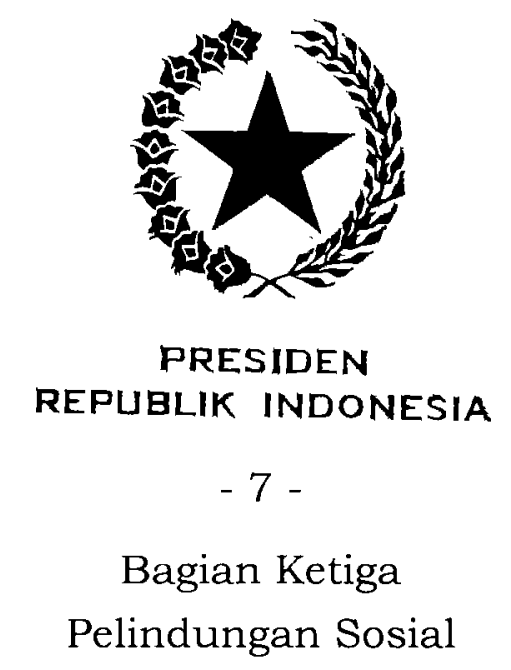

Pasal 7

(1) Pelindungan Sosial sebagaimana dimaksud dalam Pasal 4 huruf b merupakan intervensi pekerjaan sosial yang ditujukan untuk mencegah dan menangani risiko dari guncangan dan kerentanan sosial individu, keluarga, kelompok, dan masyarakat agar kelangsungan hidupnya dapat dipenuhi sesuai dengan kebutuhan dasar minimal.

(2) Pelindungan Sosial sebagaimana dimaksud pada ayat (1) dilakukan melalui:

a. bantuan sosial;

b. advokasi sosial; dan/atau

c. pemberian akses bantuan hukum.

Bagian Keempat

Rehabilitasi Sosial

Pasal 8

(1) Rehabilitasi Sosial sebagarmana dimaksud dalam Pasal 4 huruf c merupakan intervensi pekerjaan sosial yang ditujukan untuk memulihkan dan mengembangkan kemampuan individu, keluarga, kelompok, dan masyarakat yang mengalami disfungsi sosial agar dapat melaksanakan fungsi sosialnya secara wajar.

(2) Rehabilitasi Sosial sebagaimana dimaksud pada ayat (1) dapat dilaksanakan secara persuasif, motivatif, dan koersif. 


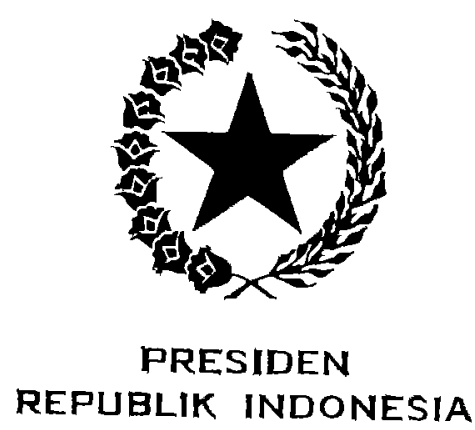

$-8-$

Pasal 9

Rehabilitasi Sosial terdiri atas:

a. Rehabilitasi Sosial dasar; dan

b. Rehabilitasi Sosial lanjut.

Pasal 10

(1) Rehabilitasi Sosial dasar sebagaimana dimaksud dalam Pasal 9 huruf a merupakan upaya yang dilakukan untuk memulihkan Keberfungsian Sosial individu, keluarga, kelompok, dan/atau masyarakat.

(2) Rehabilitasi Sosial dasar sebagaimana dimaksud pada ayat (1) dilakukan dalam bentuk:

a. motivasi dan diagnosis psikososial;

b. perawatan dan pengasuhan;

c. bimbingan mental spiritual;

d. bimbingan fisik;

e. bimbingan sosial dan konseling;

f. pelayanan aksesibilitas;

g. bantuan dan asistensi sosial; dan/atau

h. rujukan.

\section{Pasal 11}

(1) Rehabilitasi Sosial lanjut sebagaimana dimaksud dalam Pasal 9 huruf b merupakan upaya yang dilakukan untuk mengembangkan Keberfungsian Sosial individu, keluarga, kelompok, dan masyarakat.

(2) Rehabilitasi Sosial lanjut sebagaimana dimaksud pada ayat (1) dilakukan dalam bentuk:

a. motivasi dan diagnosis psikososial;

b. perawatan dan pengasuhan;

c. pelatihan vokasional dan pembinaan kewirausahaan;

d. pelayanan aksesibilitas;

e. bantuan dan asistensi sosial; 


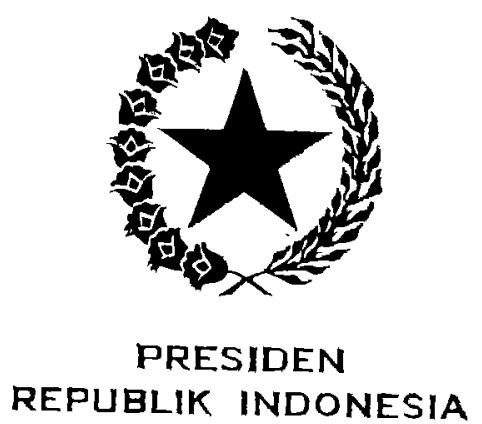

$-9-$

f. bimbingan resosialisasi;

g. bimbingan lanjut; dan/atau

h. rujukan.

(3) Selain bentuk sebagaimana dimaksud pada ayat (2) Rehabilitası Sosial lanjut juga dilakukan dalam bentuk:

a. terapi fisik;

b. terapi mental spiritual;

c. terapi psikososial;

d. terapi untuk penghidupan;

e. pemenuhan hidup layak;

f. dukungan aksesibilitas; dan/atau

g. bentuk lainnya yang mendukung Keberfungsian Sosial.

Pasal 12

Ketentuan lebih lanjut mengenai pelaksanaan Rehabilitasi Sosial sebagaimana dimaksud dalam Pasal 9, Pasal 10, dan Pasal 11 diatur dalam Peraturan Pemerintah.

\author{
Bagian Kelima \\ Pemberdayaan Sosial
}

\title{
Pasal 13
}

(1) Pemberdayaan Sosial sebagaimana dimaksud dalam Pasal 4 huruf d merupakan intervensi pekerjaan sosial yang ditujukan untuk:

a. memberdayakan individu, keluarga, kelompok, dan/atau masyarakat yang mengalami masalah sosial agar mampu meningkatkan kualitas kehidupannyá secara mandiri; dan 


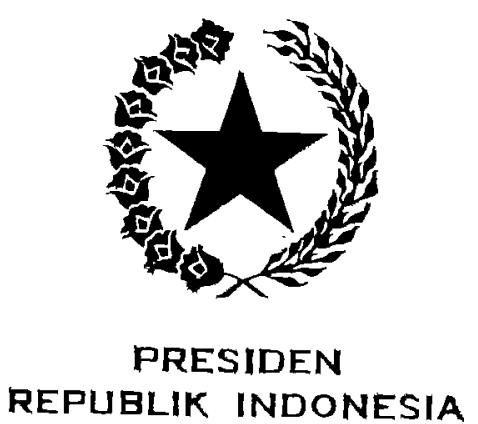

$-10-$

b. meningkatkan peran serta lembaga dan/atau perseorangan sebagai potensi dan sumber daya dalam penyelenggaraan kesejahteraan sosial.

(2) Pemberdayaan Sosial sebagaimana dimaksud pada ayat (1) dilakukan melalui:

a. identifikasi permasalahan dan sumber daya yang dapat dikembangkan;

b. penumbuhan kesadaran dan pemberian motivasi;

c. pelatihan keterampilan;

d. penguatan kelembagaan dalam masyarakat;

e. pendampingan;

f. kemitraan dan penggalangan dana;

g. pemberian akses terhadap stimulan modal, peralatan usaha, dan tempat usaha;

h. peningkatan akses pemasaran hasil usaha;

i. supervisi dan advokasi sosial;

j. penguatan keserasian sosial; dan/atau

k. bimbingan lanjut.

\author{
Bagian Keenam \\ Pengembangan Sosial
}

\title{
Pàsal 14
}

(1) Pengembangan Sosial sebagaimana dimaksud dalam Pasal 4 huruf e merupakan intervensi pekerjaan sosial yang ditujukan untuk meningkatkan dan mengembangkan kualitas kehidupan serta Keberfungsian Sosial individu, keluarga, kelompok, dan/atau masyarakat melalui partisipasi aktif atas prakarsa perseorangan, keluarga, kelompok, dan masyarakat.

(2) Pengembangan Sosial sebagaimana dimaksud pada ayat (1) dilakukan dalam bentuk:

a. pemetaan sosial;

b. advokasi ... 


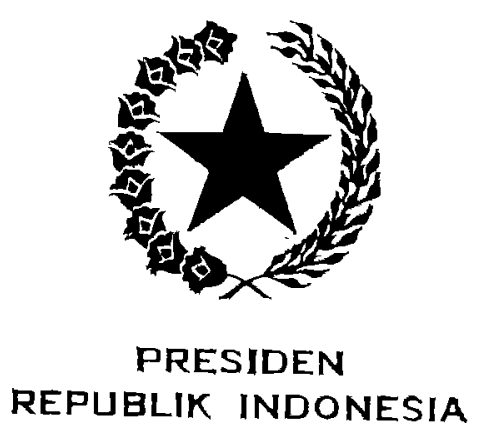

-11 -

b. advokasi sosial;

c. pendidikan psikoedukasi;

d. kampanye sosial;

e. pengembangan kemitraan;

f. peningkatan aksesibilitas;

g supervisi sosial;

h. penguatan integrasi sosial;

i. pengembangan inovasi pekerjaan sosial; dan/atau

j. Pengembangan Sosial bentuk lain.

(3) Pengembangan Sosial bentuk lain sebagaimana dimaksud pada ayat (2) huruf j ditetapkan oleh Menteri.

BAB III

STANDAR PRAKTIK PEKERJAAN SOSIAL

\section{Bagian Kesatu \\ Umum}

\section{Pasal 15}

(1) Praktik Pekerjaan Sosial dilaksanakan berdasarkan standar Praktik Pekerjaan Sosial.

(2) Standar Praktik Pekerjaan Sosial sebagaimana dimaksud pada ayat (1) meliputi:

a. standar operasional prosedur;

b. standar kompetensi Pekerja Sosial; dan

c. standar layanan.

\section{Bagian Kedua}

Standar Operasional Prosedur

\section{Pasal 16}

(1) Standar operasional prosedur sebagaimana dimaksud dalam Pasal 15 ayat (2) huruf a meliputi: 


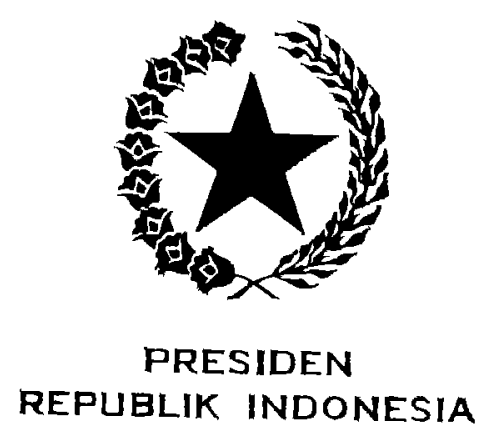

$-12-$
a. pendekatan awal;
b. asesmen;
c. perencanaan intervensi;
d. intervensi; dan
e. evaluasi, rujukan, dan terminasi.

(2) Ketentuan lebih lanjut mengenai standar operasional prosedur sebagaimana dimaksud pada ayat (1) diatur dengan Peraturan Menteri.

\section{Bagian Ketiga}

Standar Kompetensi Pekerja Sosial

\section{Pasal 17}

(1) Standar kompetensi Pekerja sosial sebagaimana dimaksud dalam Pasal 15 ayat (2) huruf b meliputi standar:

a. pengetahuan;

b. keterampilan; dan

c. nilai,

dalam Praktik Pekerjaan Sosial.

(2) Standar kompetensi Pekerja Sosial sebagaimana dimaksud pada ayat (1) disusun oleh Menteri dengan memperhatikan usulan dari Òrganisasi Pekerja Sosial.

(3) Ketentuan lebih lanjut mengenai standar kompetensi Pekerja Sosial sebagaimana dimaksud pada ayat (1) diatur dengan Peraturan Menteri. 


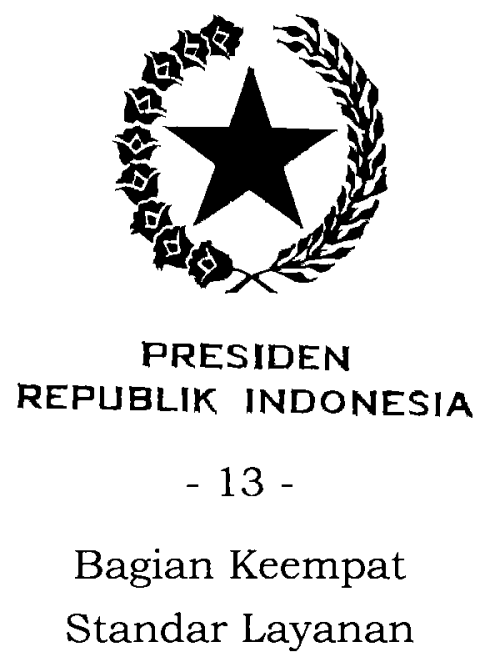

Pasal 18

(1) Standar layanan sebagaimana dimaksud dalam Pasal 15 ayat (2) huruf c dilandaskan pada fungsi Praktik Pekerjaan Sosial.

(2) Fungsi Praktik Pekerjaan Sosial sebagaimana dimaksud pada ayat (1) meliputi:
a. mencegah disfungsi sosial;
b. melaksanakan Pelindungan Sosial;
c. melaksanakan Rehabilitasi Sosial;
d. melaksanakan Pemberdayaan Sosial; dan
e. melaksanakan Pengembangan Sosial.

(3) Ketentuan lebih lanjut mengenai standar layanar sebagaimana dimaksud pada ayat (1) diatur dengan Peraturan Menteri.

\section{BAB IV}

PENDIDIKAN PROFESI PEKERJA SOSIAL

\section{Pasal 19}

Pendidikan profesi Pekerja Sosial merupakan pendiciikan setelah sarjana yang diselenggarakan oleh perguruan tinggi yang bekerja sama dengan kementerian, lembaga pemerintah nonkementerian, dan /atau organisasi profesi yang bertanggung jawab atas mutu layanan profesi.

\section{Pasal 20}

Untuk menyelesaikan pendidikan profesi Pekerja Sosial sebagaimana dimaksud dalam Pasal 19, peserta didik harus lulus Uji Kompeterisi yang bersifat nasional. 


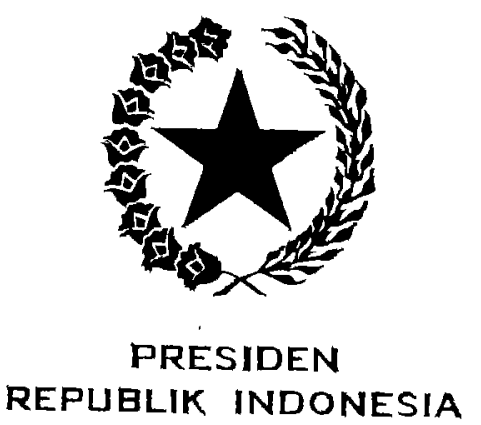

-14 -

Pasal 21

Syarat untuk mengikuti pendidikan profesi Pekerja Sosial:

a. sarjana kesejahteraan sosial;

b. sarjana terapan pekerjaan sosial; atau

c. sarjana ilmu sosial lainnya terkait kesejahteraan sosial.

Pasal 22

Untuk melakukan Praktik Pekerjaan Sosial, seseorang harus lulus Uji Kompetensi.

\section{Pasal 23}

(1) Uji Kompetensi sebagaimana dimaksud dalam Pasal 22 dilakukan melalui:

a. pendidikan profesi Pekerja Sosial; atau

b. rekognisi pembelajaran lampau.

(2) Uji Kompetensi melalui pendidikan profesi Pekerja Sosial sebagaimana dimaksud pada ayat (1) huruf a diperuntukkan bagi peserta didik pendidikan profesi Pekerja Sosial.

(3) Uji Kompetensi melalui rekognisi pembelajaran lampau sebagaimana dimaksud pada ayat (1) huruf $b$ diperuntukkan bagi setiap orang yang sudah bekerja, mempunyai pengalaman di bidang pelayanan sosial, dan/atau telah mengikuti pendidikan dan pelatihan bidang pelayanan sosial.

(4) Ketentuan lebih lanjut mengenai tata cara pelaksanaan rekognisi pembelajaran lampau untuk mengikuti Uji Kompetensi sebagaimana dimaksud pada ayat (1) huruf $b$ diatur dengan peraturan menteri yang inenyelenggarakan urusan pemerintahan di bidang pendidikan tinggi. 


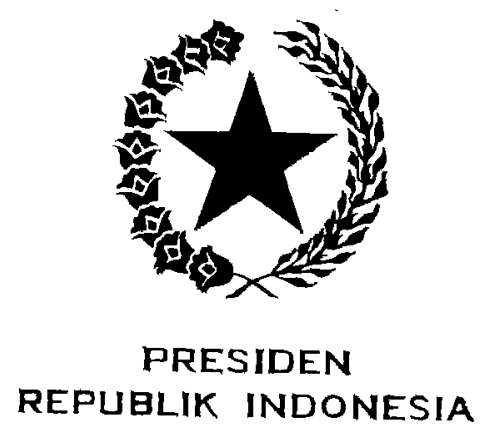

-15 -

Pasal 24

Uji Kompetensi sebagaimana dimaksud dalam Pasal 23 ayat (1) diselenggarakan oleh perguruan tinggi bekerja sama dengan Organisasi Pekerja Sosial.

Pasal 25

Peserta yang lulus Uji Kompetensi dalam pendidikan profesi sebagaimana dimaksud dalam Pasal 23 ayat (1) huruf a berhak mendapatkan sertifikat profesi dari perguruan tinggi dan Sertifikat Kompetensi dari Organisasi Pekerja Sosial serta berhak melakukan Praktik Pekerjaan Sosial.

Pasal 26

Peserta yang lulus Uji Kompetensi melalui rekognisi pembelajaran lampau sebagaimana dimaksud dalam Pasal 23 ayat (1) huruf b berhak mendapatkan Sertifikat Kompetensi dan dinyatakan sebagai Pekerja Sosial serta berhak melakukan Praktik Pekerjaan Sosial.

\section{Pasal 27}

Ketentuan lebih lanjut mengenai pendidikan profesi Pekerja Sosial dan Uji Kompetensi diatur dengan peraturan menteri yang menyelenggarakan urusan pemerintahan di bidang pendidikan tinggi berkoordinasi dengan kementerian, lembaga pemerintah nonkementerian, dan/atau Organisasi Pekerja Sosial. 


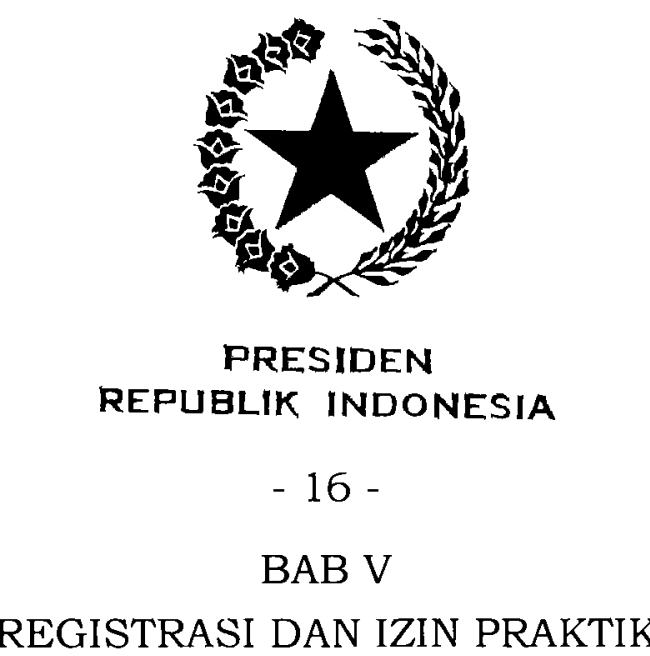

\author{
Bagian Kesatu \\ Registrasi
}

Pasal 28

(1) Setiap Pekerja Sosial yang melaksanakan Praktik Pekerjaan Sosial wajib memiliki STR.

(2) STR sebagaimana dimaksud pada ayat (1) diberikan oleh Organisasi Pekerja Sosial.

\title{
Pasal 29
}

Untuk memperoleh STR Pekerja Sosial harus memenuhi persyaratan:

a. memiliki Sertifikat Kompetensi;

b: memiliki surat keterangan kondisi jasmani dan rohani;

c. memiliki surat pernyataan telah mengucapkan sumpah/janji Pekerja Sosial; dan

d. membuat pernyataan mematuhi dan melaksanakan ketentuan kode etik Pekerja Sosial.

\section{Pasal 30}

(1) STR berlaku selama 5 (lima) tahun dan dapat diregistrasi ulang setelah memenuhi persyaratan.

(2) Persyaratan untuk Registrasi Ulang sebagaimana dimaksud pada ayat (1) meliputi:

a. memiliki STR lama;

b. memiliki Sertifikat Kompetensi;

c. memiliki surat keterangan kondisi jasmani dan rohani;

d. membuat... 


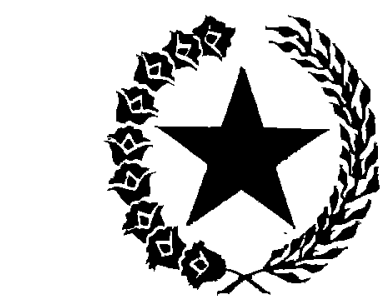

PRESIDEN

\section{REPUBLIK INDONESIA}

-17 -

d. membuat pernyataan mematuhi dan melaksanakan ketentuan kode etik Pekerja Sosial; dan

e. telah mengabdikan diri sebagai Pekerja Sosial.

Pasal 31

STR tidak berlaku karena:

a. habis masa berlakunya dan Pekerja Sosial tidak mendaftar ulang;

b. atas permintaan sendiri;

c. Pekerja Sosial meninggal dunia; atau

d. dicabut atas dasar ketentuan peraturan perundangundangan.

\section{Pasal 32}

Ketentuan lebih lanjut mengenai tata cara Registrasi dan Registrasi Ulang diatur dengan Peraturan Menteri.

\section{Bagian Kedua}

Registrasi Pekerja Sosial Lulusan Luar Negeri

\section{Pasal 33}

(1) Pekerja Sosial lulusan luar negeri yang akan melaksanakan Praktik Pekerjaan Sosial di Indonesia harus dilakukan evaluasi dan/atau verifikasi oleh Organisasi Pekeria Sosial.

(2) Evaluasi dan/atau verifikasi sebagaimana dimaksud pada ayat (1) dilakukan terhadap:

a. bukti penyetaraan ijazah oleh kementerian yang menyelenggarakan urusan pemerintahan di bidinng pendidikan tinggi;

b. surat keterangan telah mengikuti program adaptasi dan Sertifikat Kompetensi; 


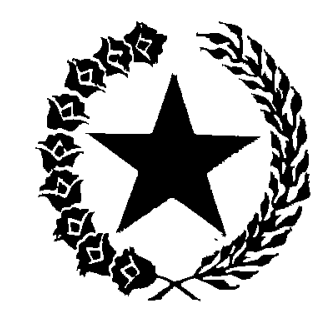

PRESIDEN

REPUBLIK INDONESIA

$-18-$

c. surat pernyataan telah mengucapkan sumpah/janji Pekerja Sosial;

d. surat keterangan kondisi jasmani dan rohani; dan

e. surat pernyataan akan mematuhi dan melaksanakan ketentuan kode etik Pekerja Sosial.

(3) Pekerja Sosial lulusan luar negeri yang telah memenuhi ketentuan sebagaimana dimaksud pada ayat (2) diberikan STR.

(4) Ketentuan lebih lanjut mengenai Registrasi Pekerja Sosial lulusan luar negeri diatur dengan Peraturan Menteri.

\section{Bagian Ketiga}

Registrasi Pekerja Sosial Warga Negara Asing

\section{Pasal 34}

(1) Pekerja Sosial warga negara asing dapat melakukan Praktik Pekerjaan Sosial di Indonesia.

(2) Pekerja Sosial warga negara asing yang melakukan Praktik Pekerjaan Sosial di Indonesia sebagaimana dimaksud pada ayat (1) harus memiliki surat izin kerja sesuai dengan ketentuan peraturan perundangundangan dan kemampuan berbahasa Indonesia.

(3) Pekerja Sosial warga negara asing yang telah memenuhi ketentuan sebagaimana dimaksud pada ayat (2) diberikan STR sementara oleh Organisasi Pekerja Sosial.

\section{Pasal 35}

(1) STR sementara dapat diberikan kepada Pekerja Sosial warga negara asing yang melakukan kegiatan pendidikan, peiatihan, penelitian, dan pelayanan di bidang kesejanteraan sosial yang bersifat sementara di Indonesia. 


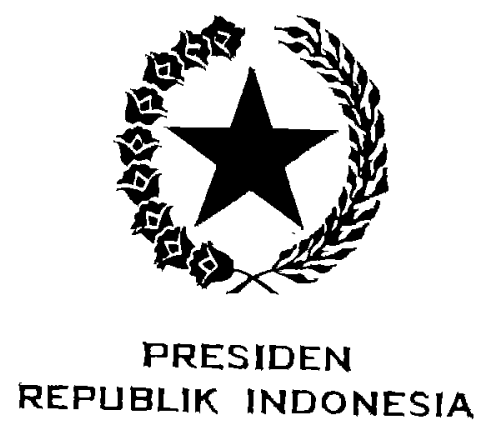

-19 -

(2) STR sementara sebagaimana dimaksud pada ayat (1) berlaku selama 1 (satu) tahun dan hanya dapat diperpanjang untuk 1 (satu) tahun berikutnya.

Pasal 36

Ketentuan lebih lanjut mengenai tata cara memperoleh STR sementara diatur dengan Peraturan Menteri.

\section{Bagian Keempat \\ Izin Praktik}

\section{Pasal 37}

(1) Pekerja Sosial yang menjalankan Praktik Pekerjaan Sosial mandiri wajib memiliki izin.

(2) Izin sebagaimana dimaksud pada ayat (1) diberikan dalam bentuk SIPPS.

(3) SIPPS sebagaimana dimaksud pada ayat (2) diberikan oleh Pemerintah Daerah kabupaten/kota tempat Pekerja Sosial menjalankan praktik mandirinya.

(4) Untuk mendapatkan SIPPS sebagaimana dimaksud pada ayat (2) dan ayat (3), Pekerja Sosial harus melampirkan:

a. salinan STR yang masih berlaku; dan

b. surat pernyataan memiliki tempat praktik atau surat keterangan dari pimpinan tempat Pekerja Sosial berpraktik.

(5) SIPPS masih berlaku apabila:

a. STR masih berlaku; dan

b. Pekerja Sosial berpraktik di tempat sebagaimana tercantum dalam SIPPS.

Pasal 38

(1) SIPPS hanya berlaku untuk 1 (satu) tempat praktik mandiri. 


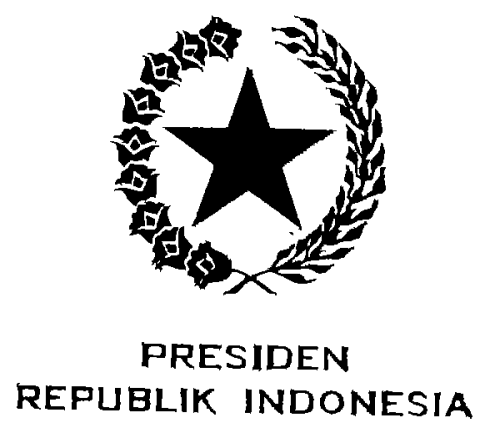

$-20-$

(2) SIPPS sebagaimana dimaksud pada ayat (1) diberikan kepada Pekerja Sosial paling banyak untuk 2 (dua) tempat praktik mandiri.

Pasal 39

SIPPS tidak berlaku karena:

a. dicabut berdasarkan ketentuan Peraturan Perundangundangan;

b. habis masa berlakunya;

c. atas permintaan Pekerja Sosial; atau

d. Pekerja Sosial meninggal dunia.

Pasal 40

Ketentuan lebih lanjut mengenai izin praktik diatur dengan Peraturan Menteri.

BAB VI

HAK DAN KEWAJIBAN

Bagian Kesatu

Hak dan Kewajiban Pekerja Sosial

Pasal 41

Pekerja Sosial dalam melaksanakan pelayanan Praktik Pekerjaan Sosial berhak:

a. memperoleh pelindungan hukum dalam pelaksanaan tugas sesuai dengan standar Praktik Pekerjaan Sosial;

b. memperoleh informasi yang benar, jelas, dan jujur dari Klien, keluarga, dan/atau pihak lain yang terkait;

c. meningkatkan kompetensi melalui pendidikan, pelatihan, dan pengembangan profesi;

d. mendapathan promosi dan/atau penghargaan sesuai dengan prestasi kerja;

e. memiliki ... 


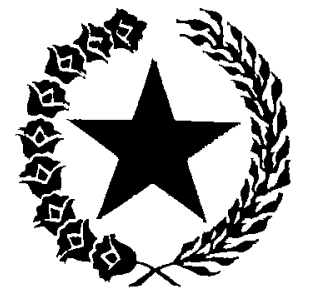 \\ PRESIDEN \\ REPUBLIK INDONESIA
}

$-21-$

e. memiliki kebebasan untuk berserikat dalam Organisasi Pekerja Sosial; dan/atau

f. menerima imbalan jasa atas pelayanan yang telah dilakukan.

\section{Pasal 42}

Pekerja Sosial dalam melaksanakan pelayanan Praktik Pekerjaan Sosial wajib:

a. memberikan pelayanan sesuai dengan standar Praktik Pekerjaan Sosial;

b. memberikan informasi yang lengkap dan benar mengenai pelayanan kepada Klien, keluarga, dan/atau pihak lain sesuai dengan kewenangannya;

c. menjaga kerahasiaan Klien;

d. merujuk Klien kepada pihak lain yang mempunyai keahlian atau kemampuan sesuai dengan penanganan masalah;

e. meningkatkan mutu pelayanan pekerjaan sosial;

f. meningkatkan dan mengembangkan kompetensi serta pengetahuan secara berkelanjutan dan/atau keterampilan melalui pendidikan dan/atau pelatihan; dan

g. bertindak objektif dan tidak diskriminatif atas dasar pertimbangan jenis kelamin, agama, suku, ras, latar belakang keluarga, disabilitas, dan status sosial ekonomi kepada Klien dalam menjalankan tugas keprofesionalan.

\author{
Bagian Kedua \\ Hak dan Kewajiban Klien
}

Pasal 43

Klien dalam menerima pelayanan Praktik Pekerjaan Sosial berhak: 


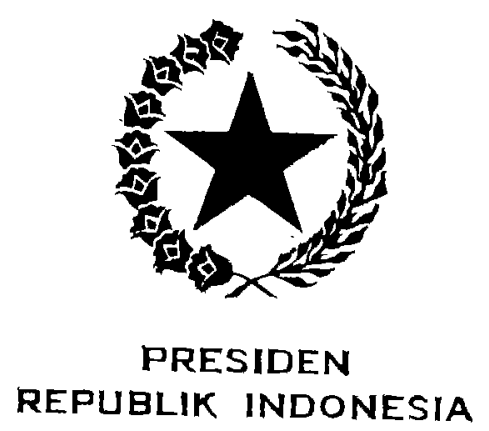

-22 -

a. memperoleh pelayanan sesuai dengan standar Praktik Pekerjaan Sosial;

b. memperoleh informasi secara benar dan jelas mengenai rencana intervensi Praktik Pekerjaan Sosial;

c. memberi persetujuan atau penolakan terhadap rencana intervensi yang akan dilakukan;

d. memperoleh jaminan kerahasiaan identitas dan kondisi Klien; dan

e. mengajukan keberatan atas pelayanan yang tidak sesuai dengan standar Praktik Pekerjaan Sosial.

Pasal 44

(1) Kerahasiaan identitas dan kondisi Klien sebagaimana dimaksud dalam Pasal 43 huruf d dapat diungkapkan atas dasar:

a. kepentingan Klien;

b. permintaan aparatur penegak hukum;

c. persetujuan Klien; dan/atau

d. perintah undang-undang.

(2) Kepentingan Klien sebagaimana dimaksud pada ayat

(1) huruf a dapat dilaksanakan dengan ketentuan:

a. memperhatikan prinsip etik dalam keadaan darurat dan/atau keselamatarı hidup; atau

b. harus dengan persetujuan Klien atau keluarga dalam keadaan tidak darurat.

\section{Pasal 45}

(1) Klien dalam menerima pelayanan Praktik Pekerjaan Sosial wajib:

a. memberikan informasi yang lengkap, jelas, dan jujur mengenai kondisinya;

b. memaiuhi nasihat dan petunjuk Pekerja Sosial; dan

c. memberikan ... 


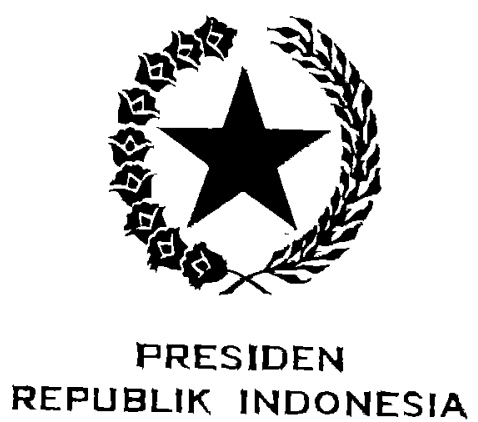

$-23-$

c. memberikan imbalan jasa atas pelayanan Praktik Pekerjaan Sosial yang diterima.

(2) Imbalan jasa sebagaimana dimaksud pada ayat (1) huruf c tidak berlaku jika Klien merupakan orang atau sekelompok orang yang tergolong miskin atau sedang dalam musibah.

\section{BAB VII}

ORGANISASI PEKERJA SOSIAL

\section{Pasal 46}

(1) Pekerja Sosial membentuk Organisasi Peikerja Sosial yang bersifat independen, mandiri, dan berbadan hukum.

(2) Organisasi Pekerja Sosial sebagaimana dimaksud pada ayat (1) berfungsi untuk meningkatkan kompetensi, karier, pelindungan, dan kesejahteraan Pekerja Sosial.

(3) Pekerja Sosial wajib menjadi anggota Organisasi Pekerja Sosial.

(4) Pembentukan Organisasi Pekerja Sosial sebagaimana dimaksud pada ayat (1) dilaksanakan sesuai dengan ketentuan peraturan perundang-undangan.

(5) Pemerintah Pusat dan/atau Pemerintah Daerah dapat memfasilitasi Organisasi Pekerja Sosial dalam pelaksanaan pembinaan dan pengembangan Pekerja Sosial.

\section{Pasal 47}

Organisasi Pekerja Sosial bertugas:

a. menyusun kode etik Pekerja Sosial;

b. melaksanakan Registrasi Pekerja Sosial;

c. meningkaikan pengetahuan, kompetensi, dan martabat Pekerja Sosial; dan 


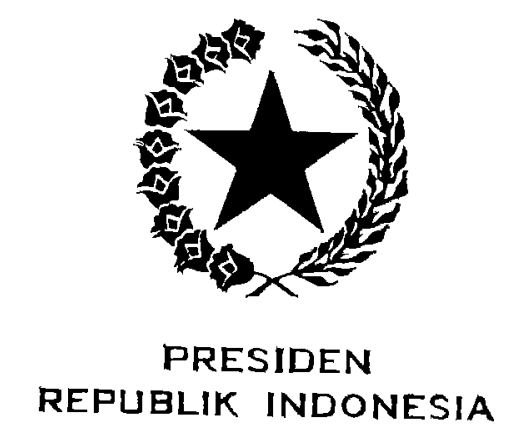

$-24-$

d. melakukan pelindungan dan pengawasan terhadap Pekerja Sosial yang melakukan Praktik Pekerjaan Sosial.

\section{Pasal 48}

Untuk melaksanakan tugas sebagaimana dimaksud dalam Pasal 47, Organisasi Pekerja Sosial berwenang:

a. menetapkan dan menegakkan kode etik Pekerja Sosial;

b. memberikan bantuan hukum kepada Pekerja Sosial;

c. melakukan pembinaan dan pengembangan Pekerja Sosial;

d. menyatakan terpenuhi atau tidaknya persyaratan Registrasi Pekerja Sosial;

e. menerbitkan, memperpanjang, membekukan, dan mencabut STR;

f. menyatakan terjadi atau tidaknya suatu pelanggaran kode etik Pekerja Sosial berdasarkan hasil investigasi;

g. menjatuhkan sanksi terhadap Pekerja Sosial yang tidak memenuhi standar Praktik Pekerjaan Sosial;

h. menjatuhkan sanksi terhadap Pekerja Sosial yang melakukan pelanggaran kode etik Pekerja Sosial; dan

i. melakukan kerja sama dengan lembaga dalam dan luar negeri untuk penyelenggaraan Praktik Pekerjaan Sosial.

BAB VIII

DEWAN KEHORMATAN KODE ETIK

Pasal 49

(1) Dewan kehormatan kode etik dibentuk oleh Organisasi Pekerja Sosial urıtuk menegakkan kode etik Pekerja Sosial.

(2) Dewan . . 


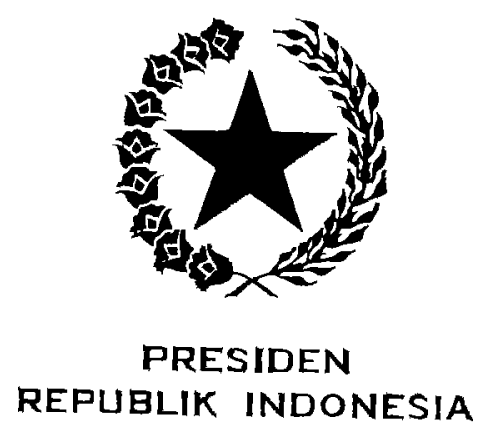

-25 -

(2) Dewan kehormatan kode etik sebagaimana dimaksud pada ayat (1) dibentuk untuk mengawasi pelaksanaan kode etik Pekerja Sosial dan memberikan rekomendasi pemberian sanksı atas pelanggaran kode etik Pekerja Sosial.

(3) Rekomendasi dewan kehormatan kode etik sebagaimana dimaksud pada ayat (2) wajib dilaksanakan oleh Organisasi Pekerja Sosial.

(4) Rekomendasi dewan kehormatan kode etik sebagaimana dimaksud pada ayat (2) harus objektif, tidak diskriminatif, dan tidak bertentangan dengan anggaran dasar Organisasi Pekerja Sosial serta ketentuan peraturan perundang-undangan.

(5) Sanksi sebagaimana dimaksud pada ayat (2) dapat berupa:

a. peringatan tertulis;

b. pembekuan sementara STR; dan/atau

c. pencabutan STR.

Pasal 50

Ketentuan mengenai keanggotaan serta mekanisme kerja dewan kehormatan kode etik diatur dengan anggaran dasar Organisasi Pekerja Sosial.

BAB IX

TUGAS DAN WEWENANG

Bagian Kesatu

Umum

Pasal 51

Pemerintah Pusat dan Pemerintah Daerah menjamin terselenggaranya Praktik Pckerjaan Sosial yang bermutu dan melindungi masyarakat penerima pelayanan Praktik Pekerjaan Sosial. 


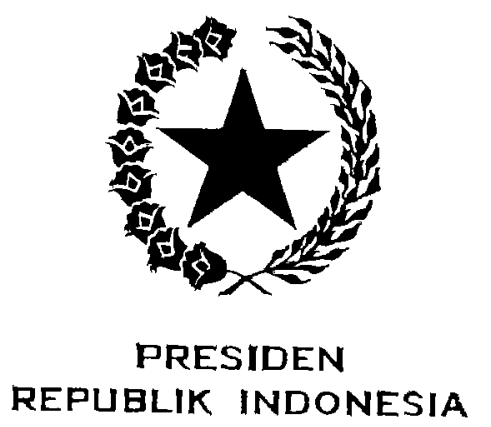

$-26-$

Bagian Kedua

Pemerintah Pusat

Pasal 52

(1) Pemerintah Pusat sebagaimana dimaksud dalam Pasal 51 bertugas:

a. menyusun standar operasional prosedur, standar kompetensi, dan standar layanan;

b. menyusun standar pendidikan Pekerja Sosial;

c. menyusun tata cara pelaksanaan Uji Kompetensi;

d. melakukan pembinaan terhadap penyelenggaran Praktik Pekerjaan Sosial bekerja sama dengan Organisasi Pekerja Sosial;

e. melakukan pengawasan penyelenggaraan Praktik Pekerjaan Sosial oleh Organisasi Pekerja Sosial;

f. mendorong tersedianya sarana pendidikan dan sumber daya dalam rangka percepatan penyelenggaraan pendidikan profesi Pekerja Sosial; dan

g. melakukan pengelolaan basis data penyelenggaraan Praktik Pekerjaan Sosial skala nasional.

(2) Dalam melakukan pembinaan sebagaimana dimaksud pada ayat (1) huruf d, Pemerintah Pusat dapat bekerja sama dengan Urganisasi Pekerja Sosial.

\section{Pasal 53}

Dalam melaksanakan tugas sebagaimana dimaksud dalam Pasal 52, Pemerintah Pusat berwenang menetapkan:

a. program pemberdayaan dan pengembangan Pekerja Sosial skala nasional;

b. kebijakan sistem Registrasi Pekerja Sosial; .

c. standar operasional prosedur, standar kompetensi, dan standar layarian; dan

d. tata cara pelaksariaan Uji Kompetensi. 


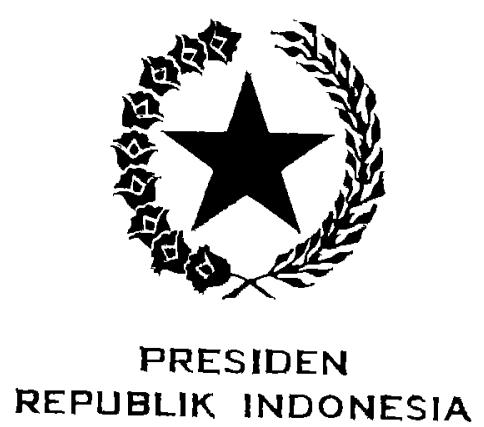

$-27-$

Pasal 54

Tugas dan wewenang Pemerintah Pusat sebagaimana dimaksud dalam Pasal 52 dan Pasal 53 dilaksanakan oleh menteri sesuai dengan tugas dan fungsinya.

\section{Bagian Ketiga \\ Pemerintah Daerah}

\section{Pasal 55}

Pemerintah Daerah sebagaimana dimaksud dalam Pasal 51 bertugas:

a. melakukan pemberdayaan dan pengembangan Pekerja Sosial;

b. melakukan pengelolaan pangkalan data pelayanan Praktik Pekerjaan Sosial di lingkup Pemerintah Daerah;

c. memfasilitasi pelayanan Praktik Pekerjaan Sosial; dan

d. melakukan pengawasan pelaksanaan Praktik Pekerjaan Sosial bersama-sama dengan Organisasi Pekerja Sosial di daerah.

Pasal 56

Dalam melaksanakan tugas sebagaimana dımaksud dalam Pasai 55, Pemerintah Daerah berwenang:

a. menetapkan program pemberdayaan dan pengembangan Pekerja Sosial di lingkup Pemerintah Darrah;

b. mendapatkan data pelayanan Praktik Pekerjaan Sosial dari pemangku kepentingan;

c. menetapkan program fasilitasi pelayanan Praktik Pekerjaan Sosial; dan

d. memberikan dar mencabut izin praktik Pekerja Sosial setelah mendapatkan rekomendasi dari dewan kehormatan kode etik Organisasi Pekerja Sosial. 


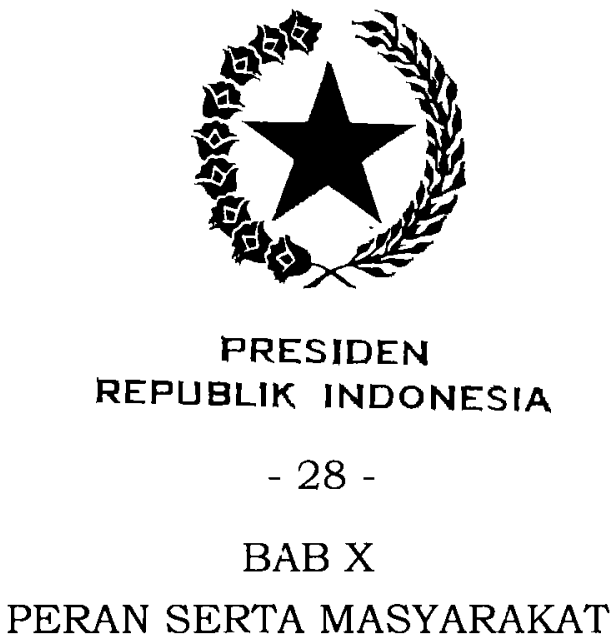

Pasal 57

Masyarakat dapat berperan aktif dalam penyelenggaraan Prakcik Pekerjaan Sosial.

\section{Pasal 58}

Peran aktif masyarakat sebagaimana dimaksud dalam Pasal 57 meliputi paling sedikit:

a. berpartisipasi dalam upaya pencegahan masalah sosial;

b. menyampaikan laporan adanya masalah sosial yang perlu penanganan Pekerja Sosial;

c. menyampaikan laporan terjadinya malpraktik yang dilakukan Pekerja Sosial;

d. melakukan pengawasan terhadap penyelenggaraan Praktik Pekerjaan Sosial; dan/atau

e. menyampaikan usulan perbaikan kebijakan terkait dengan pelaksanaan Praktik Pekerjaan Sosial.

BAB XI

KETENTUAN PERALIHAN

Pasal 59

Pada saat Undang-Undang ini mulai berlaku:

a. Pekerja Sosial yang merupakan kelompok jabatan fungsional sebelum Undang-Undang ini diundangkan tetap diakui scbagai Pekerja Sosial sesuai dengan ketentuan peraturan perundang-undangan; dan

b. Istilah pekerja sosial profesional yang digunakan dalam peraturan perundang-undangan yang sudah ada sebelum Undang-Undang ini berlaku, harus dimaknai sebagai Pekerja Sosial, sepanjang tidak bertentangan dengan Undang-Undang ini. 


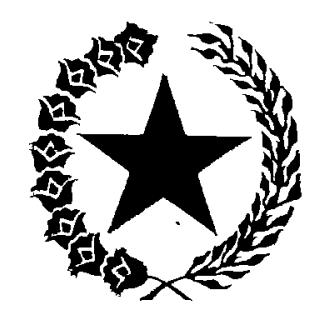

PRESIDEN

REPUBLIK INDONESIA

-29 -

Pasal 60

Berdasarkan ketentuan Undang-Undang Nomor 11

Tahun 2009 tentang Kesejahteraan Sosial (Lembaran Negara Republik Indonesia Tahun 2009 Nomor 12, Tambahan Lembaran Negara Republik Indonesia Nomor 4967):

a. Pekerja sosial profesional yang telah melakukan pelayanan sosial tetapi belum mengikuti Uji Kompetensi, masih diberikan kewenangan melakukan pelayanan sosial untuk jangka waktu paling lama 5 (lima) tahun setelah Undang-Undang ini diundangkan;

b. Pekerja sosial profesional yang belum tersertifikasi, tenaga kesejahteraan sosial, penyuluh sosial, dan relawan sosial yang telah melakukan pelayanan sosial diakui sebagai Pekerja Sosial setelah lulus Uji Kompetensi sebagaimana dimaksud dalam Pasal 23; dan

c. Pekerja sosial profesional yang telah memiliki Sertifikat Kompetensi sebelum Undang-Undang ini diundangkan, tetap diakui sebagai Pekerja Sosial menurut Undang-Undang ini.

Pasal 61

Rekognisi pembelajaran lampau dilakukan dengan ketentuan:

a. setiap orang yang sudah mempunyai pengalaman dalam pelayanan sosial tetapi tidak berlatar belakang pendidikan sarjana kesejahteraan sosial atau sarjana terapan pekerjaan sosial harus mengikuti pendidikan profesi Pekerja Sosial; dan 


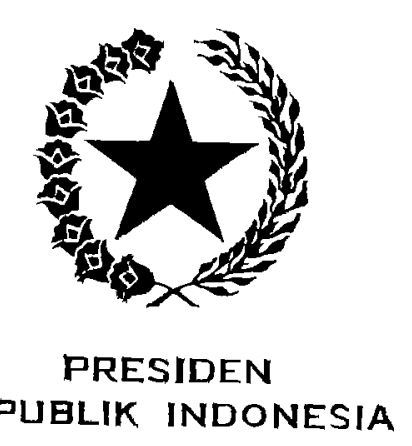

-30 -

b. setiap orang yang sudah bekerja, mempunyai pengalaman di bidang pelayanan sosial, dan/atau telah mengikuti pendidikan dan pelatiharı bidang pelayanan sosial dapat langsung mengikuti uji kompetensi sepanjang belum ada pendidikan profesi Pekerja Sosial dan paling lama 5 (lima) tahun sejak Undang-Undang ini diundangkan.

\section{Pasal 62}

Institusi yang melaksanakan Uji Kompetensi Pekerja Sosial sebelum Undang-Undang ini diundangkan masih dapat melakukan tugas dan wewenangnya sampai dengan Uji Kompetensi diselenggarakan oleh perguruan tinggi bekerja sama dengan Organisasi Pekerja Sosial.

\section{BAB XII \\ KETENTUAN PENUTUP}

\section{Pasal 63}

Organisasi Pekerja Sosial yang sudah ada harus menyesuaikan tugas dan wewenangnya berdasarkan Undang-Undang ini paling lambat 2 (dua) tahun terhitung sejak Undang-Undang ini diundangkan.

\section{Pasal 64}

Pendidikan Profesi Pekerja Sosial harus terselenggara di perguruan tinggi paling lambat 5 (lima) tahun sejak Undang-Undang ini diundangkan.

\section{Pasal 65}

Pelaksanaan Uji Kompetensi Pekerja Sosial harus diselenggarakan oleh perguruan tinggi bekerja sama dengan Organisasi Pekerja Sosial paling lama 3 (tiga) tahun sejak Undang-Undang ini diundangkan. 


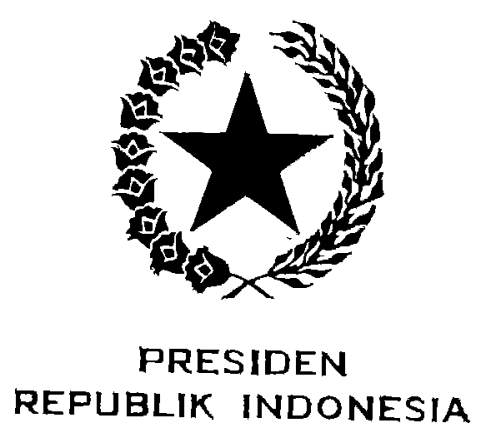

-31 -

Pasal 66

Pada saat Undang-Undang ini mulai berlaku, ketentuan yang mengatur mengenai pekerja sosial profesional dalam Pasal 1 angka 4, Pasal 33 ayat (2), Pasal 52 ayat (3) sampai dengan ayat (6) Undang-Undang Nomor 11 Tahun 2009 tentang Kesejahteraan Sosial (Lembaran Negara Republik Indonesia Tahun 2009 Nomor 12, Tambahan Lembaran Negara Republik Indonesia Nomor 4967), dicabut dan dinyatakan tidak berlaku.

Pasal 67

Pada saat Undang-Undang ini mulai berlaku, semua Peraturar Perundang-Undangan yang merupakan peraturan pelaksanaan dari peraturan perundangundangan yang berkaitan dengan Praktik Pekerjaan Sosial, dinyatakan masih tetap berlaku sepanjang tidak bertentangan dengan ketentuan Undang-Undang ini dan belum diganti dengan peraturan pelaksanaan yang baru.

Pasal 68

Peraturan pelaksanaan dari Undang-Undang ini harus ditetapkan paling lama 2 (dua) tahun sejak UndangUndang ini diundangkan.

\section{Pasal 69}

Undang-Undang ini mulai berlaku pada tanggal diundangkan. 


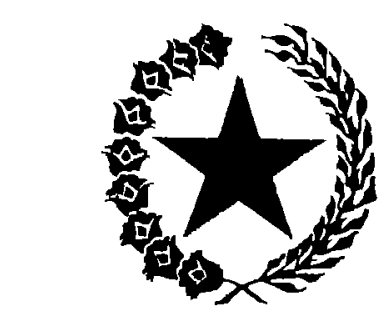

PRESIDEN

REPUBLIK INDONESIA

$-32-$

Agar setiap orang mengetahuinya, memerintahkan pengundangan Undang-Undang ini dengan penempatannya dalam Lembaran Negara Republik Indonesia.

Disahkan di Jakarta pada tanggal 1 Oktober 2019

PRESIDEN REPUBLIK INDONESIA,

ttd.

JOKO WIDODO

Diundangkan di Jakarta

pada tanggal 2 Oktober 2019

PLT. MENTERI HUKUM DAN HAK ASASI MANUSIA

REPUBLIK INDONESIA,

ttd.

TJAHJO KUMOLO

LEMBARAN NEGARA REPUBLIK INDONESIA TAHUN 2019 NOMOR 182

Salinan sesuai dengan aslinya

KEMENTERIAN SEKRETARIAT NEGARA

REPUBLIK INDONESIA

Deputi Bum dan Perundang-undangan,

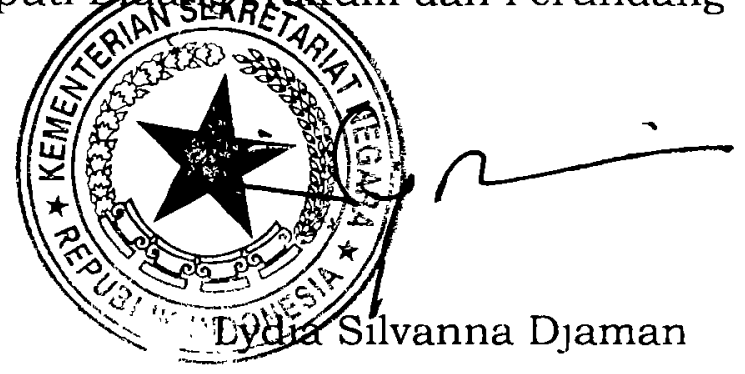




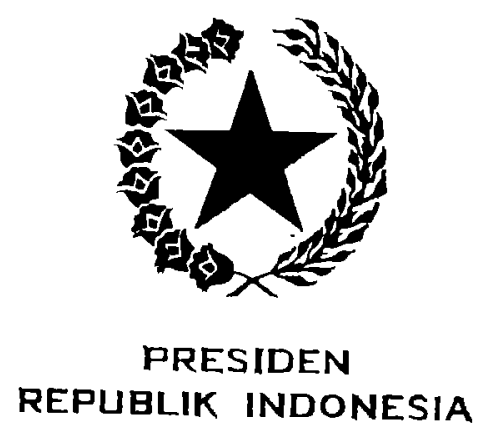

PENJELASAN

ATAS

UNDANG-UNDANG REPUBLIK INDONESIA

NOMOR 14 TAHUN 2019

TENTANG

PEKERJA SOSIAL

I. UMUM

Penyelenggaraan kesejahteraan sosial merupakan bagian integral dari pembangunan nasional sebagai perwujudan dari upaya mencapai tujuan bangsa yang diamanatkan dalam Undang-Undang Dasar Negara Republik Indonesia Tahun 1945 dan perwujudan nilai Pancasila. Penyelenggaraan kesejahteraan sosial salah satunya ditujukan untuk mengatasi berbagai masalah kesejahteraan sosial yang dihadapi individu, keluarga, kelompok, dan masyarakat agar mampu meningkatkan kualitas dan standar kehidupannya secara adil dan merata.

Penyelenggaraan kesejahteraan sosial yang dilakukan selama ini oleh Pemerintah belum sepenuhnya mampu mengatasi permasalahan sosial di masyarakat. Selain itu, adanya perubahan sosial di masyarakat berdampak pada meningkatnya masalah sosial dan disertai dengan munculnya masalah sosial baru. Masalah sosial yang dialami atau dihadapi selama ini oleh individu, keluarga, kelompok, dan masyarakat belum diberikan pelayanan yang sesuai dengan standar Praktik Pekerjaan Sosial serta ketersediaan Pekerja Sosial yang tidak sebanding dengan jumlah Klien.

Pada saat ini belum ada peraturan perundang-undangan yang mengatur tentang Pekerja Sosial. Pengaturan Pekerja Sosial sangat diperlukan sebagai pedoman formal (legalitas) bagi Pekerja Sosial dalam melaksanakan praktiknya di Indonesia. Selain itu, Pekerja Sosial sebagai salah satu komponen utama penyelenggara kesejahteraan sosial kepada masyarakat mempunyai peranan penting sehingga perlu mendapatkan pelindungan dan kepastian hukum. 


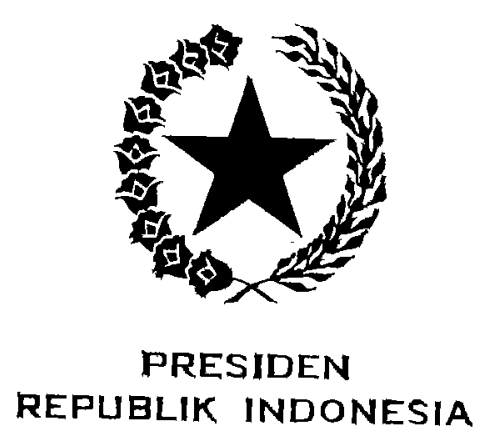

$-2-$

Pekerja Sosial dalam melaksanakan pelayanan Praktik Pekerjaan Sosial yang ditujukan bagi individu, keluarga, kelompok, dan masyarakat dilakukan melalui pelayanan yang terencana, terpadu, berkualitas, dan berkesinambungan sesuai dengan standar Praktik Pekerjaan Sosial. Pelayanan Praktik Pekerjaan Sosial bertujuan:

a. mencegah terjadinya disfungsi sosial individu, keluarga, kelompok, dan masyarakat;

b. memulihkan dan meningkatkan Keberfungsian Sosial individu, keluarga, kelompok, dan masyarakat;

c. meningkatkan ketahanan sosial masyarakat dalam menghadapi masalah kesejahteraan sosial;

d. meningkatkan kualitas manajemen penyelenggaraan kesejahteraan sosial dalam rangka mencapai kemandirian individu, keluarga, kelompok, dan masyarakat; dan

e. meningkatkan kemampuan dan kepedulian masyarakat dalam penyelenggaraan kesejahteraan sosial secara melembaga dan berkelanjutan.

Undang-Undang tentang Pekerja Sosial mengatur mengenai pertama, Praktik Pekerjaan Sosial yang merupakan cakupan kegiatan Praktik Pekerjaan Sosia! dan bentuk kegiatan yang dapat dilakukan; kedua, standar Praktik Pekerjaan Sosial yang berisi standar yang harus dipenuhi dalam melakukan pelayanan Praktik Pekerjaan Sosial dan standar tersebut ditentukan oleh Menteri; ketiga, Pendidikan Profesi Pekerja Sosial yang mengatur kompetensi seseorang untuk menjadi Pekerja Sosial sehingga memiliki kompetensi untuk melakukan Praktik Pekerjaan Sosial; keempat, Registrasi dan izin praktik yang mengatur mengenai kewajiban memiliki STR dan SIPPS, Pekerja Sosial lulusan luar negeri, dan Pekerja Sosial warga negara asing; kelima, hak dan kewajiban Pekerja Sosial dan Klien; keenam, Organisasi Pekerja Sosial sebagai wadah aspirasi Pekerja Sosial; ketujuh, Dewan Kerhormatan Kode Etik yang dibentuk oleh Organisasi Pekerja Sosial; kedelapan tugas dan wewenang Pemerintah Pusat dan Pemerintah Daerah yang bertujuan untuk menjamin mutu dan pelindungan masyarakat penerima layanan Praktik Pekerjaan Sosial; kesembilan, peran serta masyarakat dalam penyelenggaraan Praktik Pekerjaan Sosial. 


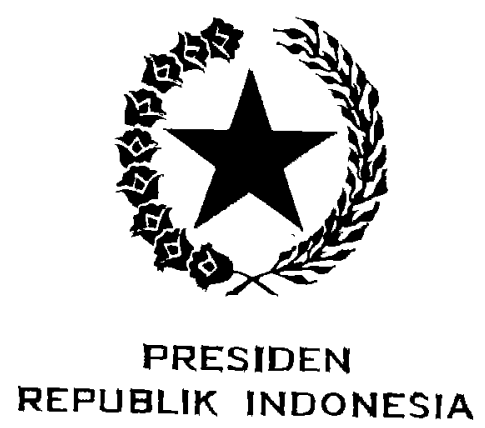

$-3-$

II. PASAL DEMI PASAL

Pasal 1

Cukup jelas.

Pasal 2

Huruf a

Yang dimaksud dengan "asas nondiskriminatif" adalah bahwa Praktik Pekerjaan Sosial dilaksanakan dengan tidak membeda-bedakan suku, agama, ras, antar golongan, dan status sosial.

Huruf $b$

Yang dimaksud dengan "asas kesetiakawanan" adalah bahwa pelaksanaan Praktik Pekerjaan`Scsial dilandasi oleh kepedulian sosial untuk membantu orang yang membutuhkan pertolongan dengan empati dan kasih sayang.

Huruf c

Yang dimaksud dengan "asas keadilan" adalah bahwa Praktik Pekerjaan Sosial dilaksanakan dengan memberikan pelayanan secara merata dan proporsional sesuai dengan kebutuhan setiap individu, keluarga, kelompok, dan masyarakat.

\section{Huruf d}

Yang dimaksud dengan "asas profesionalitas" adalah bahwa Praktik Pekerjaan Sosial dilaksanakan berdasarkan pada ilmu pengetahuan, keterampilan, nilai, dan etika pekerjaan sosial.

Huruf e

Yang dimaksud dengan "asas kemanfaatan" adalah bahwa Praktik Pekerjaan Sosial harus memberikan manfaat untuk pemecahan masalah dan peningkatan kualitas hidup. 


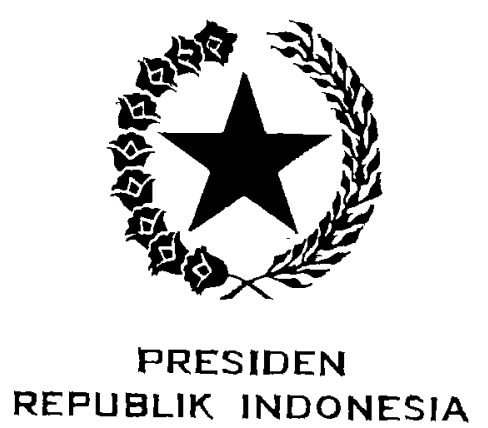

$-4-$

Huruf $f$

Yang dimaksud dengan "asas keterpaduan" adalah bahwa Praktik Pekerjaan Sosial harus terintegrasi dengan berbagai pemangku kepentingan terkait dan sistem sumber daya kesejahteraan sosial sehingga dapat dilaksanakan secara terkoordinasi, sinergis, dan optimal.

Huruf g

Yang dimaksud dengan "asas kemitraan" adalah bahwa pelaksanaan Praktik Pekerjaan Sosial diperlukan kerja sama dengan berbagai profesi dan masyarakat dalam memperbaiki dan meningkatkan Keberfungsian Sosial individu, keluarga, kelompok, dan masyarakat.

Huruf $h$

Yang dimaksud dengan "asas aksesibilitas" adalah bahwa dalam pelaksanaan Praktik Pekerjaan Sosial, Pekerja Sosial harus memberikan akses yang seluas-luasnya kepada Klien atau keluarga untuk mendapatkan informasi yang benar mengenai permasalahan dan penanganan Klien.

Huruf i

Yang dimaksud dengan "asas akuntabilitas" adalah bahwa Pekerja Sosial harus dapat mempertanggungjawabkan pelayanan Praktik Pekerjaan Sosial yang diberikan kepada Klien.

Pasal 3

Cukup jelas.

Pasal 4

Cukup jelas. 


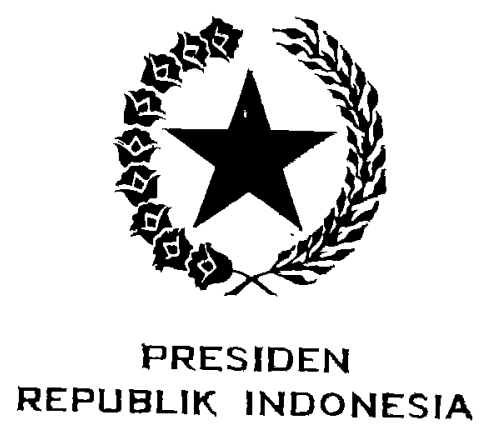

$-5-$

Pasal 5

Yang dimaksud dengan "sarana dan prasarana pelayanan" adalah segala sesuatu yang dapat dipakai sebagai alat dar segala sesuatu yang dapat menjadi penunjang utama bagi Pekerja Sosial untuk memberikan pelayanan kepada Klien yang mencakup antara lain gedung/kantor, ruang konseling, dan laboratorium.

Pasal 6

Ayat (1)

Cukup jelas.

Ayat (2)

Huruf a

Yang dimaksud dengan "penyuluhan sosial" adalah suati proses pengubahan perilaku yang dilakukan melalui penyebarluasan informasi, komunikasi, motivasi, dan edukasi, baik secara lisan, tulisan maupun peragaan kepada individu, keluarga, kelompok, dan/atau masyarakat.

Huruf b

Yang dimaksud dengan "bimbingan sosial" adalah bimbingan yang dılakukan kepada Klien dalam menghadapi dan mernecahkan masalah sosial.

Huruf c

Yang dimaksud dengan "pendampingan sosial" adalah interaksi dinamis antara Pekerja Sosial dengan Klien untuk bersama-sama menghadapi dan memecahkan masaiah sosial yang dihadapi Klien.

Huruf d

Yang dimaksud dengan "peningkatan kapasitas" adalah suatu proses untuk melakukan perubahan dan meningkatkan kemampuan pada individu, keluarga, kelornpok, dan/atau masyarakat dalam menyelesaikan masaleh sosial.

Huruf e ... 


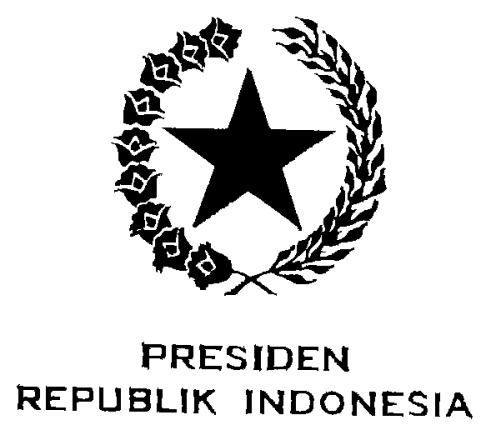

$-6-$

Huruf e

Yang dimaksud dengan "pelatihan keterampilan" adalah pelatihan untuk meningkatkan kemampuan Klien dalam hal tertentu yang dapat berguna bagi diri Klien dan lingkungan sosialnya.

Huruf $\mathrm{f}$

Yang dimaksud dengan "pelayanan aksesibilitas" adalah pelayanan yang diberikan untuk memudahkan Klien mengakses berbagai sistem sumber yang dibutuhkan sesuai dengan haknya.

Huruf g

Yang dimaksud dengan "advokasi sosial" adalah kegiatan yang dilakukan untuk melindungi dan membela Klien dalam memperoleh haknya, misalnya melalui penyadaran, pembelaan, dan pemenuhan hak.

Huruf $h$

Cukup jelas.

Ayat (3)

Cukup jelas.

Pasal 7

Cukup jelas.

Pasal 8

Ayat (1)

Cukup jelas.

Ayat (2)

Yang dimaksud dengan "Rehabilitasi Sosial secara persuasif" adalah rehabilitasi yang dilaksanakan oleh Pekerja Sosial melalui ajakan, anjuran, dan bujukan dengan maksud untuk meyakinkan Klien agar bersedia dan patuh menjalani tahap rehabilitasi. 


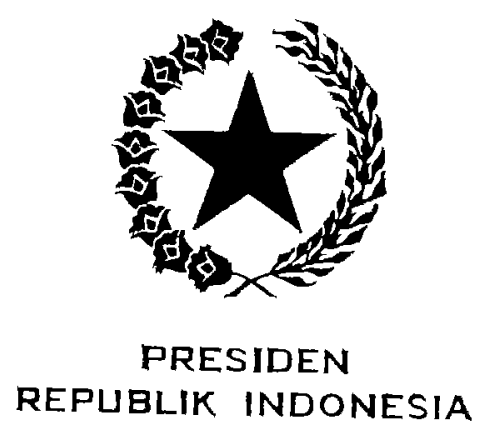

$-7-$

Yang dimaksud dengan "Rehabilitasi Sosial secara motivatif" adalah Rehabilitasi Sosial yang dilaksanakan oleh Pekerja Sosial melalui dorongan, pemberian semangat, pujian, dan/atau penghargaan agar Klien tergerak secara sadar untuk direhabilitasi.

Yang dimaksud dengan "Rehabilitasi Sosial secara koersif" adalah Rehabilitasi Sosial yang dilaksanakan oleh Pekerja Sosial melalui tindakan yang dilakukan dalam kondisikondisi tertentu dan bukan atas kemauan sendiri untuk direhabilitasi dengan memperhatikan hak asasi Klien agar kembali tenang dan dapat menerima proses rehabilitasi.

Pasal 9

Cukup jelas.

Pasal 10

Ayat (1)

Cukup jelas.

Ayat (2)

Huruf a

Yang dimaksud dengan "motivasi dan diagnosis psikososial" adalah upaya untuk memberikan dorongan, semangat, daya kreatif, dan melakukan diagnosis psikososial kepaca Klien untuk mengembalikan dan/atau meningkatkan Keberfungsian sosial.

Huruf b

Yang dimaksud dengan "perawatan dan pengasuhan" adalah upaya untuk menjaga, melindungi, merawat, dan mengasuh Klien agar dapat melaksanakan fungsi sosial. 


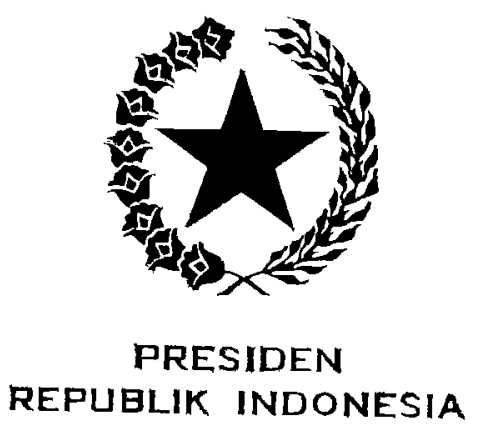

$-8-$

Huruf c

Yang dimaksud dengan "bimbingan mental spiritual" adalah upaya untuk memberikan bimbingan kepada Klien agar memiliki ketenangan dan kepercayaan bahwa kehidupan yang lebih baik akan dapat dicapai.

Huruf d

Yang dimaksud dengan "bimbingan fisik" adalah upaya untuk memelihara dan meningkatkan kesehatan jasmani Klien.

Huruf e

Yang dimaksud dengan "bimbingan sosial dan konseling" adalah semua bentuk pelayanan bantuan psikologis yang ditujukan untuk mengatasi masalah psikososial agar dapat meningkatkan Keberfungsian Sosial.

Huruf $f$

Yang dimaksud dengan "pelayarıan aksesibilitas" adalah pelayanan yang diberikan untuk memudahkan Klien mengakses berbagai sistem sumber yang dibutuhkan sesuai dengan haknya.

Huruf g

Yang dimaksud dengan "bantuan dan asistensi sosial" adalah upaya yang dilakukan berupa pemberian bantuan kepada Klien yang mengalami guncangan dan kerentanan sosial agar dapat hidup secara wajar.

Huruf h

Yang dirnaksud dengan "rujukan" adalah upaya untuk mengalihkan layanan kepada pihak lain agar Klien memperoleh pelayanan lanjutan atau sesuai dengan kebutuhan.

Pasal 11

Ayat (1)

Cukup jelas. 


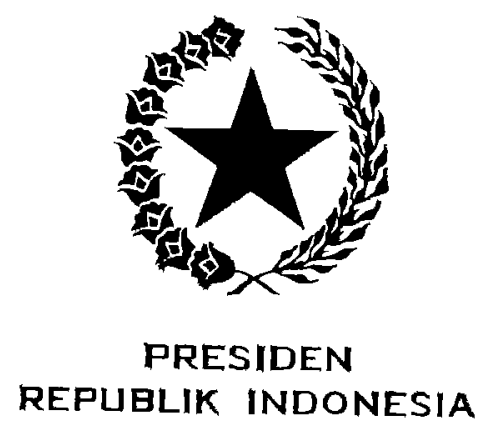

$-9-$

Ayat (2)

Huruf a

Cukup jelas.

Huruf b

Cukup jelas.

Huruf c

Yang dimaksud dengan "pelatihan vokasional dan pembinaan kewirausahaan" adalah usaha pemberian keterampilan kepada Klien agar mampu hidup mandiri dan/atau produktif.

Huruf d

Cukup jelas.

Huruf e

Cukup jelas.

Huruf $f$

Yang dimaksud dengan "bimbingan resosialisasi" adalâh kegiatan untuk mempersiapkan Klien agar dapat diterima kembali ke dalam keluarga dan masyarakat.

Huruf g

Yang dimaksud dengan "bimbingan lanjut" adalah kegiatan pemantapan kemandirian Klien setelah memperoleh pelayanan Rehabilitasi Sosial.

Huruf $h$

Cukup jelas.

Ayat (3)

Huruf a

Yang dimaksud dengan "terapi fisik" adalah upaya untuk mengoptimalkan, memelihara, dan mencegah kerusakan atau gangguan fungsi fisik yang dilakukan dengan cara antara lain latihan terapeutik dan dukungan alat bantu. 


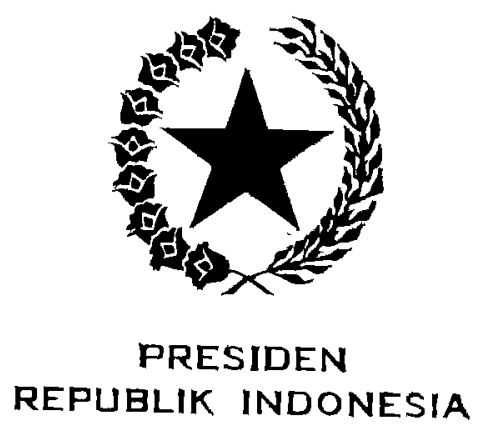

$-10-$

Huruf b

Yang dimaksud dengan "terapi mental spiritual" adalah terapi yang menggunakan nilai moral, spiritual, dan agama untuk membantu Klien menemukan makna hidup, mengatasi kecemasan, dan depresi.

Huruf c

Yang dimaksud dengan "terapi psikososial" adalah kumpulan terapi untuk mengatasi masalah interaksi Klien dengan lingkungan sosialnya, baik keluarga, kelompok, maupun masyarakat.

Huruf d

Yang dimaksud dengan "terapi untuk penghidupan" adalah berbagai kegiatan untuk meningkatkan produktivitas kehidupan Klien yang dilakukan dengan cara antara lain meningkatkan pengetahuan dan keterampilan, memfasilitasi lingkungan kerja yang strategis agar Klien dapat hidup mandiri.

Huruf e

Yang dimaksud dengan "pemenuhan hidup layak" adalah upaya untuk memenuhi kebutuhan Klien agar dapat hidup layak.

Huruf $f$

Cukup jelas.

Huruf g

Cukup jelas.

Pasal 12

Cukup jelas.

Pasal 13

Ayat (1)

Cukup jelas. 


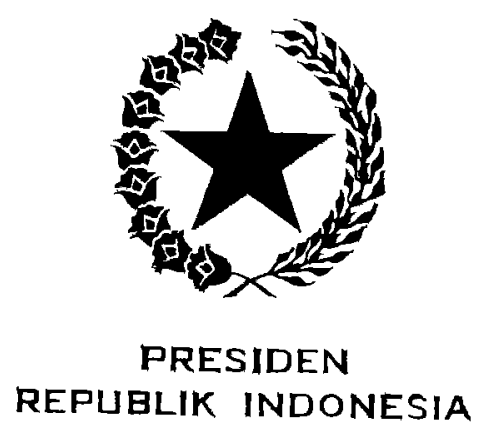

$-11-$

Ayat (2)

Huruf a.

Yang dimaksud dengan "identifikasi permasalahan dan sumber daya yang dapat dikembangkan" adalah upaya untuk melakukan penggalian data/informasi secara mendetail terkait permasalahan Klien, identifikasi potensi dan sumber daya untuk memahami kebutuhan Klien.

Huruf $b$

Yang dimaksud dengan "penumbuhan kesadaran dan pemberian motivasi" adalah upaya untuk membantu Klien dengan cara menumbuhkan kesadaran akan potensi yang dimilikinya serta memberikan motivasi untuk bangkit dan berkembang agar lebih berdaya secara sosial.

Huruf c

Yang dimaksud dengan "pelatihan keterampilan" adalah upaya untuk memberikan pelatihan, pengetahuan, dan keterampilan kepada Klien sesuai dengan minat dan bakat.

Huruf d

Penguatan kelernbagaan dalam masyarakat antara lain dilakukan dengan kegiatan memberikan bimbingan dan pengembangan sumber daya manusia, serta mengembangkan kapasitas kepemimpinan dan kelembagaan.

Huruf e

Cukup jelas.

Huruf $\mathrm{f}$

Cukup jelas.

Huruf g

Cukup jelas. 


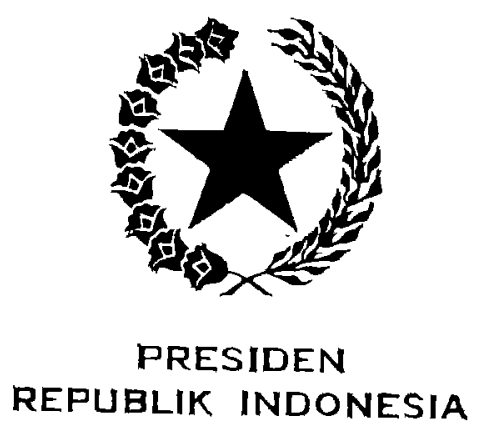

$-12-$

Huruf $h$

Cukup jelas.

Huruf i

Cukup jelas.

Huruf $j$

Cukup jelas.

Huruf k

Cukup jelas.

Pasal 14

Ayat (1)

Cukup jelas.

Ayat (2)

Huruf a

Yang dimaksud dengan "pemetaan sosial" adalah upaya untuk membantu Klien untuk menemukan dan mengenali masalah, potensi, dan sumber yang dapat digunakan untuk meningkatkan kualitas hidup dan Keberfungsian Sosial Klien.

Huruf b

Cukup jelas.

Huruf c

Cukup jelas.

Huruf d

Yang dimaksud dengan "kampanye sosial" adalah upaya membantu fengembangan pemahaman Klien antara lain secara lisan, tulisan, dan peragaan kepada masyarakat.

Huruf e

Yang dimaksud dengan "pengembangan kemitraan" adalah upaya membantu pengembangan Klien dengan cara membangun kerja sama dengan pemangku kepencingan yang saling menguntungkan. 


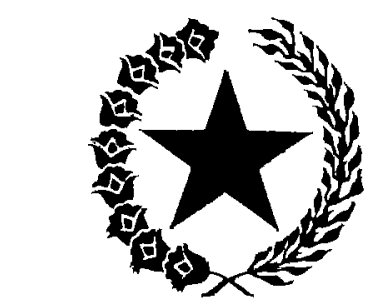

PRESIDEN

REPUBLIK INDONESIA

$-13-$

Huruf $f$

Yang dimaksud dengan "peningkatan aksesibilitas" adalah upaya untuk membantu pengembangan Klien dengan cara menghubungkan Klien dengan berbagai sumber.

Huruf g

Yang dimaksud dengan "supervisi sosial" adalah upaya membantu pengembangan Klien antara lain dengan cara memberikan bimbingan, pendampingan, dan fasilitasi terkait fungsi sosial.

Huruf $h$

Yang dimaksud dengan "penguatan integrasi sosial" adalah upaya membantu Klien untuk berintegrasi dengan lingkungannya.

Huruf i

Cukup jelas.

Huruf j

Cukup jelas.

Ayat (3)

Cukup jelas.

Pasal 15

Cukup jelas.

Pasai 16

Cukup jelas.

Pasal 17

Cukup jelas.

Pasal 18

Cukup jelas. 


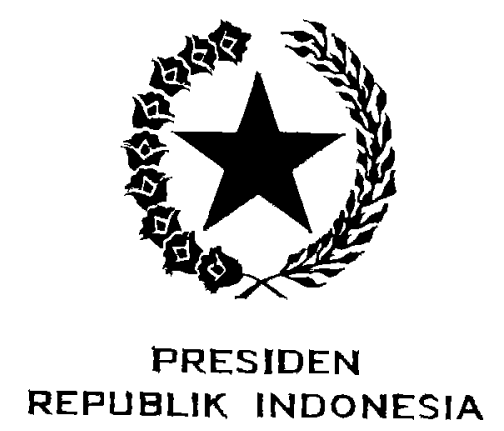

$-14-$

Pasal 19

Cukup jelas.

Pasal 20

Cukup jelas.

Pasal 21

Huruf a

Cukup jelas.

Huruf b

Cukup jelas.

Huruf c

Yang dimaksud dengan "ilmu sosial lainnya terkait kesejahteraan sosial" antara lain pembangunan sosial dan

kesejahteraan, pemberdayaan masyarakat, serta sosiologi.

Pasal 22

Cukup jelas.

Pasal 23

Ayat (1)

Huruf a

Cukup jelas.

Huruf b

Yang dimaksud dengan "rekognisi pembelajaran lampau" adalah pengakuan atas capaian pembelajaran seseorang yang diperoleh dari pendidikan formal atau nonformal atau informal, dan/atau pengalaman kerja di bidang pelayanan sosial pada jenjang pendidikan tinggi.

Ayat (2)

Cukup jelas.

Ayat (3)

Cukup jelas.

Ayat (4) ... 


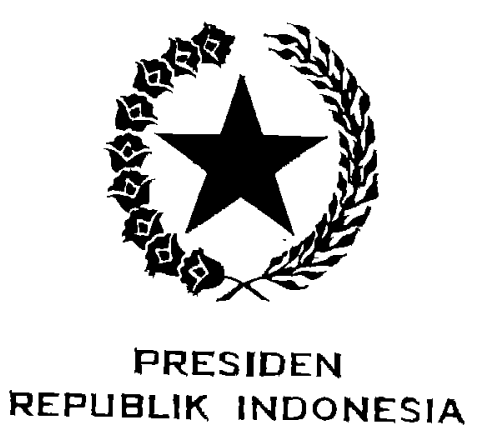

-15 .

Ayat (4)

Cukup jelas.

Pasal 24

Cukup jelas.

Pasal 25

Cukup jelas.

Pasal 26

Cukup jelas.

Pasal 27

Cukup jelas.

Pasal 28

Cukup jelas.

Pasal 29

Huruf a

Cukup jelas.

Huruf b

Yang dimaksud dengan "surat keterangan kondisi jasmani

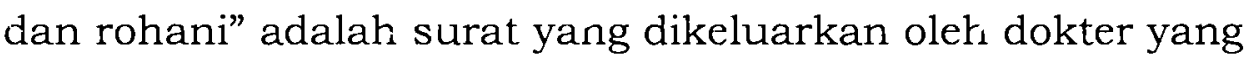
menjelaskan terkait kondisi jasmani dan rohani untuk dapat bekerja sebagai Pekerja Sosial.

Huruf c

Cukup jelas.

Huruf d

Cukup jelas.

Pasal 30

Cukup jelas 


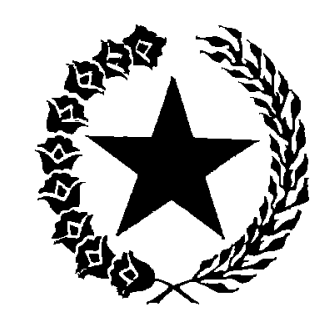

PRESIDEN

REPUBLIK INDONESIA

- 16 -

\section{Pasal 31}

Cukup jelas.

\section{Pasal 32}

Cukup jelas.

\section{Pasal 33}

Cukup jelas.

Pasal 34

Cukup jelas.

\section{Pasal 35}

Cukup jelas.

Pasal 36

Cukup jelas

\section{Pasal 37}

Cukup jelas.

Pasal 38

Cukup jelas.

\section{Pasal 39}

Cukup jelas:

Fasal 40

Cukup jelas.

Pasal 41

Cukup jelas. 
PRESIDEN

REPUBLIK INDONESIA

- 17 -

Pasal 42

Cukup jelas.

Pasal 43

Cukup jelas.

Pasal 44

Cukup jelas.

Pasal 45

Cukup jelas.

Pasal 46

Cukup jelas.

Pasal 47

Cukup jelás.

Pasal 48

Cukup jelas.

Pàsal 49

Ayat (1)

Cukup jelas.

Ayat (2)

Cukup jelas.

Ayat (3)

Cukup jelas.

Ayar (4)

Cukup jelas.

Ayat (5)

Huruf a

Cukup jelas. 


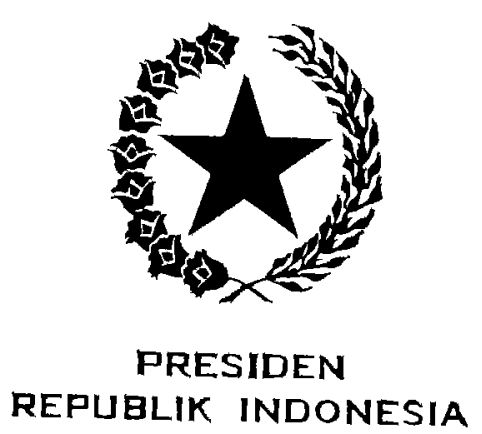

- 18 -

Huruf b

Yang dimaksud dengan "pembekuan sementara STR" adalah sanksi yang diberikan dalam bentuk penghentian sementara kegiatan Praktik Pekerjaan Sosial.

Huruf c

Cukup jelas.

Pasal 50

Cukup jelas.

Pasal 51

Cukup jelas.

Pasal 52

Cukup jelas.

Fasal 53

Cukup jelas.

Pasal 54

Cukup jelas.

Pasal 55

Cukup jelas.

Pasa! 56

Cukup jelas.

Pasal 57

Cukup jelas.

Pasal 58

Cukup jelas. 


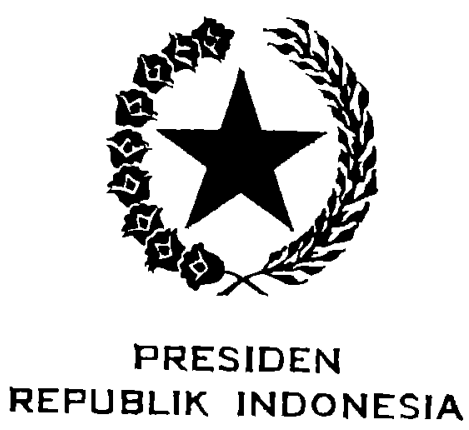

$-19-$

Pasal 59

Cukup jelas.

Pasal 60

Cukup jelas.

Pasal 61

Cukup jelas.

Pasal 62

Cukup jelas.

Pasal 63

Cukup jelas.

Pasal 64

Cukup jelas.

Pasal 65

Cukup jelas.

Pasal 66

Cukup jelas.

Pasal 67

Cukup jelas.

Pasal 68

Cukup jelas.

Pasal 69

Cukup jelas.

TAMBAHAN LEMBARAN NEGARA. REPUBI,IK INDONESIA NOMOR 6397 